\title{
Career Choices: Navy Psychiatry
}

\author{
Siddhi Bhivandkar, MD, and Captain Paulette T. Cazares, MD, MPH
}

Editor's note: Career Choices features a psychiatry resident/fellow interviewing a psychiatrist about why they have chosen a specific career path. The goal is to inform trainees about the various psychiatric career options, and to give them a feel for the pros and cons of the various paths.

$\mathrm{n}$ this Career Choices, Siddhi Bhivandkar, MD, spoke with Captain Paulette T. Cazares, MD, MPH. Dr. Cazares is Director for Mental Health at U.S. Navy Medicine Readiness and Training Command Okinawa, Japan. She also is Assistant Professor, Department of Psychiatry, Uniformed Services University, Bethesda, Maryland, and serves as Secretary of the American Medical Women's Association, Schaumburg, Illinois.

Dr. Bhivandkar: What made you choose the Navy psychiatry track, and how did your training lead you towards this path?

Dr. Cazares: I had considered a career in the Navy early on in my education, and when I was ready to apply to medical school, I saw Uniformed Services University (USU) as one of my top choices. I wasn't $100 \%$ sure, but after a tour and my interview, I was sold on serving those who serve.

During my clinical rotations at USU, I had great experiences in inpatient and emergency psychiatry. I became fascinated with understanding all I could about brain circuitry and chemistry, and how that interacts with the environment to create or protect individuals from disease. Once I talked with some mentors, it became clear to me

that I would love a career in psychiatry, and that remains true today.

Dr. Bhivandkar: What are some of the pros and cons of working in Navy psychiatry?

Dr. Cazares: As a Navy psychiatrist, I have found great reward in caring for our nation's volunteer force. I have had wonderful colleagues with whom I have deployed, and with whom I have served in both small military hospitals and large military training and academic centers. I have been able to work in research in military mental health, and feel I have specifically advanced the field of women's mental health in the Navy.

I had 4 children while I have been on active duty, and had paid maternity leave for all of them, as well as practices that protected my choice to breastfeed and pump, even after returning to work. I have moved to areas of the country I didn't expect to with the Navy, and my husband's career took unexpected turns as a result. While this can be seen as a challenge, it can also be a surprisingly rewarding experience, seeing areas of our nation and world that I otherwise would not have seen. I have deployed and been away from family. While that was a challenge, my family came through it very

LET YOUR VOICE BE HEARD

CURRENT PSYCHIATRY invites psychiatry residents to share their views on professional or clinical topics for publication in Residents' Voices. E-mail jbauer@mdedge.com for author guidelines.

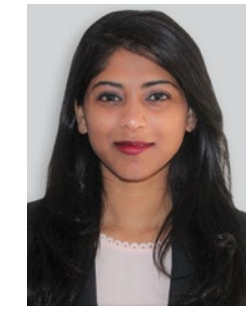

Siddhi Bhivandkar, MD

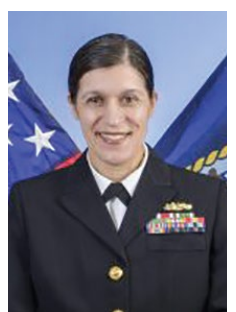

Captain Paulette T. Cazares, MD, MPH

Dr. Bhivandkar is a PGY-2 Psychiatry Resident, Saint Elizabeth's Medical Center, Boston, Massachusetts. Dr. Cazares is Director for Mental Health at U.S. Navy Medicine Readiness and Training Command Okinawa, Japan.

Disclosures

The authors report no financial relationships with any companies whose products are mentioned in this article, or with manufacturers of competing products.

doi: $10.12788 /$ cp.0083 
Clinical Point

We are part of the multidisciplinary team that helps to build resilience in our young service members

Discuss this article at www.facebook.com/ MDedgePsychiatry strong, and I found myself a more humble human and a better clinician as a result of that time.

Dr. Bhivandkar: Based on your personal experience, what should one consider when choosing a Navy psychiatry program?

Dr. Cazares: In considering a Navy training program, one should consider that in the military, our patient population is generally young and healthy, yet also exposed to unique occupational stressors. This means that we generally see routine mental health diagnoses, and some early-break severe cases. We do not typically follow longterm patients with chronic mental illness, because those patients tend to be medically retired from active duty service.

We see many unique populations that have specific health care needs, including service members who work on submarines, who are pilots or military police members, and those who handle and manage weapons. We get to learn the unique balance between serving our patients, and the units they work for and in. We see the impact of occupational stress on individuals, and are part of the multidisciplinary team that helps to build resilience in our young service members.

Dr. Bhivandkar: What are some of the career options and work settings for Navy psychiatrists?
Dr. Cazares: My peers and I have worked across both operational and multiple hospital settings, with both the US Marine Corps, as well as the US Navy. Psychiatrists can apply for fellowship, as the Navy regularly trains child and adolescent psychiatrists, as well as those who want to specialize in addiction psychiatry.

We can work in large Navy medical centers on faculty, in community-style Navy hospitals both in the United States and overseas, as well as on ships, with the Marines, or in headquarters jobs, advising on policy and the future of the military health system.

Dr. Bhivandkar: What are some of the challenges of working in this field?

Dr. Cazares: Health care and the military are both demanding career fields. Like many areas of medicine, work-life harmony is an important part of a career in Navy psychiatry. I work hard to balance my own needs, and model this for those I lead.

Dr. Bhivandkar: What advice do you have for those contemplating a career in Navy psychiatry?

Dr. Cazares: Consider joining a team that offers incredible purpose. I have served wonderful patients and had incredibly impressive colleagues, and I am grateful for the choice I made to take an oath and wear the uniform. 